\title{
Okul Yöneticilerinin Ertelemecilik Davranışları, İş Yükleri ve Kişilik Özelliklerine ilişkin Algıları
}

\author{
Dr. Melike CÖMERT(Öğr. Üyesi) \\ inönü Üniversitesi-Türkiye \\ melike.comert@inonu.edu.tr
}

\author{
Prof. Dr. Burhanettin DÖNMEZ \\ Inönü Üniversitesi-Türkiye \\ burhanettin.donmez@inonu.edu.tr
}

\begin{abstract}
Özet:
Okul yöneticilerinin; ertelemecilik davranışlarına, iş yüklerine ve kişilik özelliklerine ilişkin algılarını belirlemeyi amaçlayan çalışma, Malatya ili merkez ilçe belediye sınırları içerisindeki ilkokul ve ortaokullarda görev yapan 77 müdür, 193 müdür yardımcısı olmak üzere toplam 270 okul yöneticisi ile yürütülmüştür. Araştırmada "tarama (survey)" modeli kullanılmıştır. veriler, araştırmacı tarafından geliştirilen "Okul Yöneticileri Ertelemecilik Davranışları Ölçeği", "Rol Kaynaklı İşyükü Ölçeği" ve "5 Faktör Kişilik Özellikleri Ölçeği" kullanılarak toplanmıştır. Ayrıca cinsiyet, branş, görev türü, okul türü değişkenleri ile ertelemecilik, iş yükü ve kişilik özellikleri arasındaki ilişkiler de incelenmiş ve yorumlanmıştır. Araştırma bulgularına göre, yöneticiler ertelemecilik davranışlarını "kısmen" sergilemekte, iş yüklerini orta düzeyde algılamakta, kişilik ölçeğinin sorumluluk alt boyutuna "çoğunlukla", geçimlilik alt boyutuna "orta düzeyde", duygusal denge alt boyutuna ise "çoğunlukla" katılmaktadırlar. Ertelemecilik ile iş yükü arasında orta düzeyde pozitif yönde $(r=.602, p=.01)$, ertelemecilik ile sorumluluk kişilik özelliği arasında orta düzeyde negatif yönde ( $r=-.496, p=.01)$, iş yükü ile sorumluluk ( $r=-.321, p=.01)$ arasında ise düşük düzeyde negatif yönde ilişki bulunmuştur. Çalışma bulgularından hareketle görevlerin ertelenmemesi için yöneticilerin içten denetimli olmaları, görevleri içselleştirmeleri için yüksek bir iş doyumuna ve örgütsel bağllık düzeyine de sahip olmaları beklenmektedir. Yöneticilerin etkili zaman yönetimi ve içten denetim becerilerinin geliştirilmesi sağlanmalıdır.
\end{abstract}

Keywords: Okul yöneticisi, ertelemecilik davranışları, iş yükü, kişilik özellikleri.

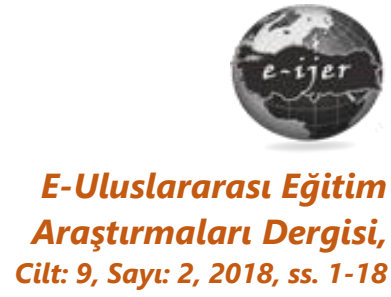

DOI: 10.19160/ijer.409300

Gönderim : 24.03.2018 Kabul : 24.05.2018

\section{Önerilen Atıf}

Cömert, M. \&. Dönmez, B. (2018). Okul yöneticilerinin ertelemecilik davranışları, iş yükleri ve kişilik özelliklerine ilişkin algıları, E-Uluslararası Eğitim Araştırmaları Dergisi, Cilt: 9: , Sayı: 2, 2018, ss. 1-18, DOI: 10.19160/ijer.409300 


\section{Giriş}

Yapılan araştırmalar, işleri erteleme davranışınn ya da işleri erteleme eğiliminin toplumun her kesiminden bireylerde yaygın olarak görülen bir sorun olduğunu göstermektedir (Çakıcı, 2003; Kandemir, 2017). İspanya, Peru, Venezuela, İngiltere, Avusturya ve ABD'den 1347 kişinin katılımıyla yürütülen bir çalışmaya (Ferrari ve ark., 2007) katılan kadın ve erkeklerin yaklaşık \%15'i kendilerini ertelemeci olarak tanımlamışlardır. Ferrari, Johnson ve McCown (1995) da "Ertelemecilik ve Görevden Kaçma: Kuram, Araştırma ve Tedavi" başlıklı kitaplarında, ertelemeciliğin tarih boyunca var olduğunu ancak kavramın tamamıyla modern bir olgu olduğunu belirtmektedirler. Solomon ve Rothblum (1984; akt. Sarıkaya Aydın ve Koçak, 2016) ertelemeciliği, genellikle rahatsızlık verici duygular uyandıran bir işi, görevi, ya da sorumluluğu sebepsiz yere geciktirme davranışı olarak tanımlamaktadır. Milgram ve Tenne (2000), ise ertelemeciliği, bir kişilik özelliği ya da davranışsal olarak işleri geciktirmeye yatkın olma, görev yapmaktan ya da karar vermekten kaçınma olarak tanımlamaktadır. Ertelemecilik genel anlamda; bir görevi yürütmek için gerekli kaynaklara, yetkiye ve becerilere sahip olunmasına rağmen, bilinçli bir şekilde bir göreve başlamayı, sürdürmeyi ve tamamlamayı gereksiz ya da amaçsız olarak erteleme ve bu durumu alışkanlık haline getirme olarak tanımlanabilir. Bu bağlamda ertelemecilik; duygusal, bilişsel ve davranışsal boyutları olan karmaşık bir süreç olarak tanımlanabilir (Chu ve Choi, 2005).

Ertelemecilik ile kişilik özellikleri arasında ilişki olabileceği düşünülmektedir. Atkinson ve arkadaşlarına (1999) göre kişilik, bir kişinin fiziksel ve sosyal ortamılla etkileşme tarzını ortaya koyan, düşünce, duygu ve davranışın ayırt edici ve karakteristik görüntüleridir. Cüceloğlu (1993) kişiliği, bireyin iç ve dış çevresiyle kurduğu, diğer bireylerden ayırt edici, tutarlı ve yapılaşmış bir ilişki biçimi olarak tanımlamaktadır. Bu araştırmada okul yöneticilerinin ertelemecilik davranışları ile bazı kişilik özellikleri arasında ilişki olabileceği düşünülmüştür. Yapılan literatür incelemesinde, ertelemecilik ve kişilik özellikleri ile ilgili çalışmalarda, Beş Faktör Kişilik Modeli ve bu modele uygun farklı Beş Faktör Kişilik Envanterlerinin kullanıldığı görülmüştür (Johnson ve Blum, 1995; Lay ve Brokenshire, 1997; Watson, 2001). Bu nedenle, bu araştırmada da yöneticilerin kişilik özelliklerini belirlemek üzere, geçerlik ve güvenirlik çalışmaları Tomrukçu (2008) tarafından yapılan, Beş Faktör Kişilik Özellikleri Ölçeği kullanılmıştır.

Etkili okul ve okul etkililiği, son dönemlerde eğitim alanındaki araştırmacıların ve uygulamacıların en çok kullandığı kavramlar olmakla beraber, Okulların etkililiğini ve verimliliğini etkileyen pek çok etken vardır. Bu etkenler arasında, okuldaki eğitim-öğretim faaliyetlerinin niteliğini etkileyen en önemli unsurlardan biri okul yöneticileridir. Okul örgütlerini yönetmekle görevli olan okul yöneticileri, okul içinde süregelen işlerin tamamından (özlük hakları, okul binasının işletilmesi, okul içinde ve dışındaki izlenim yönetimi, üst yönetim, çevre ve kişilerarası ilişkiler) sorumludur (Baltacı, 2017).Okul yöneticilerinin bu denli yoğun bir iş yükü olması, onların çeşitli işleri öncelik sırasına koymasına ve bazılarını da ertelemesine yol açmaktadır. Okullardaki iş yoğunluğuna rağmen, okul yöneticilerinin kişilik özellikleri bu işlerle başa çıkmalarını sağlayan en önemli kaynaklarıdır. Okul yöneticisinin kişilik özelliği onların iş performanslarını, işe yönelik tutumlarını, özyeterliklerini ve işdoyumları gibi çok çeşitli durumları etkilemektedir (Baltacı, 2017).

Son yıllarda; başta gelişmiş ülkeler olmak üzere okulların niteliğinin artırılmasında ve nitelikli bir toplum oluşturmada eğitim yöneticilerine hayatî sorumluluklar düştüğü konusunda görüş birliği vardır (Şişman ve Turan, 2004). Okul yöneticilerinin, okulun yönetimi ile ilgili olarak rol ve sorumluluklarının tamamı, onların iş yükünü oluşturmaktadır.

Yukarıda değinilen kuramsal çerçeve ışığında, bu araştırmanın temel amacı, okul yöneticilerinin ertelemecilik davranışlarını, iş yüklerini ve kişilik özelliklerini okul yöneticilerinin algılarına dayalı olarak belirlemektir. 


\section{YÖNTEM}

\section{Araştırma Modeli}

Araştırma; düzeyine göre uygulama, çevresine göre saha, yöntemine göre ise tarama (survey) modelinde betimsel bir araştırma olarak nitelendirilebilir. Bu model, davranış bilim ve disiplinlerine daha uygun düşmekte ve yöntemin özellikleri gereği, kurumların "ne" olduğunu anlamak ve betimlemek, kurumun mevcut düzenini bozmadan ve kurum personeline yönetsel güçlük çıkarmadan yapılabilmektedir (Cohen, Manion ve Morrison 2000; Kaptan, 1993: 60).

\section{Çalışma Grubu}

Araştırmada veri toplama araçlarının daha sağlıklı doldurulmasını sağlamak ve araştırmanın geçerlilik ve güvenirliğini arttırmak için, pilot uygulama ve asıl uygulama çalışmaları iki farklı yönetici evreni üzerinde yürütülmüştür. Pilot uygulamanın yürütüldüğü birinci grup, ertelemecilik ölçeğinin geliştirilmesi sürecine katılan yöneticileri kapsamaktadır. Bu grubun evrenini, Bingöl ili merkez ilçe sınırları içerisindeki ilkokul ve ortaokullarda görev yapan, 34 okul müdürü ve 93 müdür yardımcısı olmak üzere toplam 127 okul yöneticisi oluşturmaktadır. Bu grup için evrenin ulaşılabilir nitelikte olduğu düşünülmüş, örneklem alınmadan evrenin tamamına ulaşılmaya çalışılmıştır. Eksik ve hatalı doldurulan ölçeklerin elenmesinden sonra, geçerlik ve güvenirlik çalışmaları için, toplam 121 okul yöneticisi tarafından doldurulan ölçme araçları değerlendirmeye alınmıştır.

Araştırmanın asıl uygulama aşamasını oluşturan ikinci grubun evreni, Malatya ili merkez ilçe belediye sınırları içerisindeki ilkokul ve ortaokullarda görev yapan, 110 okul müdürü ve 258 müdür yardımcısı olmak üzere toplam 368 okul yöneticisinden oluşmaktadır. Araştırmanın örneklemi ise evrendeki okul yöneticilerinden araştırmaya katılmayı gönüllü olarak kabul eden 77 müdür, 193 müdür yardımcısı olmak üzere toplam 270 okul yöneticisinden oluşmaktadır.

\section{Veri Toplama Araçları}

$\mathrm{Bu}$ araştırmanın verileri, üç farklı ölçek kullanılarak toplanmıştır. Okul yöneticilerinin ertelemecilik davranışlarına ilişkin algılarını belirlemek için araştırmacı tarafından geliştirilen "Okul Yöneticileri Ertelemecilik Davranışları Ölçeği" kullanılmıştır. Ölçek geliştirilme aşamasında; ertelemeciliğe ilişkin kuramsal yaklaşımlar ve yapılan araştırmalar incelenmiş, benzer ölçme araçlarından elde edilen bilgiler, müfettiş, yönetici ve öğretmenlerden alınan görüşler ışığında yöneticilerin okul yönetiminde sergiledikleri ertelemecilik davranışlarına ilişkin 97 maddelik denemelik ölçek formu oluşturulmuştur. Müdürlerden toplanan verilere faktör analizi yapılmadan önce verilerin dağılım özellikleri incelenmiş ve tüm maddelerin çarpıklık ve sivrilik değerleri 1 e yakın bulunmuştur. Bu aşamadan sonra yapılan Kaiser Mayer-Olkin (.84) ve Bartlett's Test of Sphericity $=687,695, \mathrm{df}=91, \mathrm{p}=.000$ ) testleri sonucunda verilerin faktör analizine uygun olduğu belirlenmiştir. Yinelenen analizler sonucunda ölçeğin tek boyut ve on dört maddeden oluşan bir yapıya sahip olduğu belirlenmiştir. Yapılan analizler sonucunda, maddelerin faktör yüklerinin. 46 ile .76 arasında değiştiği belirlenmiştir. Ölçekte yer alan maddelerin, made toplam korelasyon katsayıları ise .52 ile .76 arasında değişmektedir. Ölçeğin açıkladığı toplam varyans oranı \% 38.75 olarak belirlenmiştir.

Araştırmada, yöneticilerin iş yükleri ile ertelemecilik davranışlarının ilişkili olabileceği düşünülmüştür. Bu nedenle yöneticilerin, iş yüklerine ilişkin algılarını belirlemek için, orijinali Reilly (1982) tarafından geliştirilen, Türkçe için geçerlik ve güvenirlik çalışması araştırmacı tarafından yapılan "Rol Kaynakı iş yükü Ölçeği" kullanılmıştır. Araştırmada ayrıca, okul yöneticilerinin kişilik özellikleri ile erteleme davranışları arasında bir ilişki olabileceği düşünülmüştür. Bu nedenle yöneticilerin kişilik özelliklerini belirlemek için, geçerlik ve güvenirlik çalışmaları Tomrukçu (2008) tarafından yapılan"5 Faktör Kişilik Özellikleri Ölçeği" kullanılmıştır. 


\section{Verilerin Analizi}

Araştırmada elde edilen verilerin analizinde öncelikle, varyansların homojenliğini test etmek için Levene'nin Varyansların Homojenliği Testi yapılmış, varyansların homojen olduğu durumlarda; algılar arasında cinsiyet, branş, görev türü değişkenlerine göre anlamlı bir fark olup olmadığını test etmek amacıyla t-testi, okul türü değişkenlerine göre anlamlı bir fark olup olmadığını test etmek amacıyla tek yönlü varyans analizi yapılmıştır. Okul yöneticilerinin ertelemecilik davranışları, iş yükleri ve kişilik özelliklerine ilişkin algıları arasındaki ilişkinin belirlenmesi için ise Pearson Korelasyon Analizi yapılmıştır. Varyansların homojen olmadığı durumlarda, t-testi yerine Mann Whithney- $U$, tek yönlü varyans analizi yerine Kruskall Wallis- $\mathrm{H}$ Testi yapılmıştır. Ölçme aracı ile elde edilen verilerin istatistiksel çözümlemesinde SPSS 14.0 (Statistical Package for The Social Sciences) paket programından yararlanılmıştır.

\section{BULGULAR}

Araştırmanın ana amacı olan okul yöneticilerinin, ertelemecilik davranışlarına, iş yüklerine ve kişilik özelliklerine ilişkin algı düzeylerini belirlemek için, katılımcıların ölçeklerden aldıkları toplam puanlar üzerinden betimsel istatistik hesaplamaları yapılmıştır. Analiz sonuçları Tablo 1 'de yer almaktadır.

\section{Tablo 1:}

Okul Yöneticilerinin Ertelemecilik, Iş̧ yükü ve Kişilik Özellikleri Ölçeklerinden Aldıkları Puanlara ilişkin Betimsel istatistikler

\begin{tabular}{|c|c|c|c|c|c|c|}
\hline \multicolumn{2}{|l|}{ Boyut } & $\mathrm{N}$ & Minimum & Maksimum & $\bar{X}$ & SS \\
\hline \multicolumn{2}{|c|}{ Ertelemecilik } & 270 & 14 & 70 & 19,73 & 5,22 \\
\hline \multicolumn{2}{|l|}{ İş yükü } & 270 & 9 & 45 & 21,44 & 5,79 \\
\hline \multirow{3}{*}{ 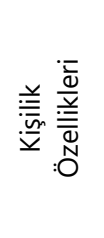 } & Sorumluluk & 270 & 9 & 45 & 37,40 & 7,38 \\
\hline & Geçimlilik & 270 & 9 & 45 & 26,87 & 3,44 \\
\hline & Duygusal Denge & 270 & 7 & 35 & 14,62 & 5,21 \\
\hline
\end{tabular}

Araştırmaya katılan okul yöneticilerinin ertelemecilik ölçeğinden aldıkları puanların aritmetik ortalaması $\bar{X}=19,73$ olarak hesaplanmıştır. Ertelemecilik ölçeğinden alınabilecek yüksek puanların okul yöneticilerinin erteleme eğilimlerinin fazla olduğunu, düşük puanların ise erteleme eğilimlerinin az olduğunu gösterdiği göz önünde bulundurulduğunda, okul yöneticilerinin ölçekte yer alan ertelemecilik davranışlarını "kısmen" $[\bar{X}=1,41 \quad(19,73 / 14)]$ sergiledikleri söylenebilir.

Yöneticilerin iş yükü ölçeğinden aldıkları puanların aritmetik ortalaması $\bar{X}=21,44$ olarak hesaplanmıştır. İş yükü ölçeğinden alınabilecek minimum ve maksimum puanlar incelendiğinde, araştırmaya katılan yöneticilerin ölçekte yer alan ifadelere "orta düzeyde" [ $\bar{X}=2,38(21,44 / 9)]$ katıldıkları görülmektedir. Bu bulgu, yöneticilerin iş yüklerini "orta düzeyde" algıladıklarını göstermektedir. 
Yöneticilerin kişilik ölçeğinin sorumluluk alt boyutundan aldıkları puanların aritmetik ortalaması $\bar{X}=37,40$ olarak hesaplanmıştır. Ölçekten alınabilecek en yüksek puanın 45 olduğu göz önünde bulundurulduğunda, araştırmaya katılan yöneticilerin ölçekte yer alan ifadelere "çoğunlukla" [ $\bar{X}=4.15(37,40 / 9)]$ katıldıkları görülmektedir. Bu bulgu araştırmaya katılan okul yöneticilerinin kendilerini oldukça sorumluluk sahibi bireyler olarak algıladıklarını göstermektedir. Sorumluluk sahibi bireylerin çalışkan, titiz ve görev odaklı olması beklenmektedir. Yöneticilik görevinin doğası gereği de yöneticilerin kendilerini sorumlu kişilik özelliğine sahip bireyler olarak algılamaları beklenen bir durum olarak görülmektedir.

Kişilik ölçeğinin geçimlilik alt boyutuna ilişkin bulgular incelendiğinde ise, araştırmaya katılan yöneticilerin aritmetik ortalamalarının $\bar{X}=26,87$ olduğu görülmektedir. Kişilik ölçeğinin, geçimlilik boyutundan alınabilecek yüksek puanların geçimli bir kişilik özelliğini temsil ettiği düşünüldüğünde, araştırmaya katılan yöneticilerin kendilerini "orta düzeyde" [ $\bar{X}=2,99(26,87 / 9)]$ geçimli olarak algıladıkları söylenebilir. Antonioni, (1998) tarafından yapılan araştırmalarda (Akt: Yürür, 2009) yüksek düzeyde geçimlilik özelliğine sahip bireylerin hükmetme tarzına sahip olmadıkları tespit edilmiştir. Bu bağlamda araştırmada da yöneticilerin kendilerini orta düzeyde geçimli algılamaları, hükmetme tarzını kullanarak yöneticilik yapıyor olabileceklerini düşündürmektedir.

Araştırmaya katılan yöneticilerin, kişilik ölçeğinin duygusal denge alt boyutuna ilişkin aritmetik ortalamaları $\bar{X}=14,62$ olarak hesaplanmıştır. Bu bulgu araştırmaya katılan yöneticilerin ölçekte yer alan ifadelere "kısmen" $[\bar{X}=2,09(14,62 / 7)]$ katıldıklarını göstermektedir. Ölçekten alınan düşük puanların duygusal açıdan dengeli bir kişilik özelliğini temsil ettiği düşünüldüğünde, katılımcıların kendilerini "çoğunlukla" duygusal olarak dengeli kişilik özelliğine sahip bireyler olarak algıladıkları söylenebilir. Yöneticiler görevleri gereği öğretmen, veli, öğrenci baskılarıyla ya da sorunlarıyla çok sık karşılaşmaktadırlar. Bu nedenle yöneticilerin sorun çözme, çatışma yönetme becerileri gelişmekte; daha sakin, soğukkanlı, tutarlı kararlar alabilmektedirler. Yöneticilerin kendilerini daha dengeli bireyler olarak algılamaları bir ölçüde bu duruma bağlanabilir. Yürür (2009) tarafından yapılan çalışmada bu yorumu destekler nitelikte olup, duygusal olarak dengesizlik özelliği gergin, endişeli, alıngan kişileri tanımlamakta olup, bu duygularda bireyin herhangi bir çatışmayı, sorunu çözme becerisini zayıflatmaktadır.

\section{Tablo 2:}

Okul Yöneticilerinin Ertelemecilik Davranışları, Iş Yükleri ve Kişilik Özelliklerine Ilişskin Algılarının Cinsiyet Değişkenine Göre Analiz Sonuçları

\begin{tabular}{|c|c|c|c|c|c|c|c|}
\hline \multicolumn{2}{|c|}{ Boyut } & Cinsiyet & $\mathbf{N}$ & $\bar{X}$ & SS & $\mathbf{U}$ & $\mathbf{p}$ \\
\hline \multirow{2}{*}{\multicolumn{2}{|c|}{ Ertelemecilik }} & Kadın & 15 & 15,73 & 1,79 & \multirow{2}{*}{916,50} & \multirow{2}{*}{, $00^{*}$} \\
\hline & & Erkek & 255 & 19,97 & 5,26 & & \\
\hline \multirow{2}{*}{\multicolumn{2}{|c|}{ İş yükü }} & Kadın & 15 & 16,66 & 3,95 & \multirow{2}{*}{911,50} & \multirow[t]{2}{*}{, $00^{*}$} \\
\hline & & Erkek & 255 & 21,72 & 5,77 & & \\
\hline \multirow{6}{*}{ 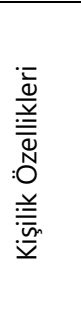 } & \multirow[t]{2}{*}{ Sorumluluk } & Kadın & 15 & 38,00 & 4,86 & \multirow[t]{2}{*}{1802,50} & \multirow[t]{2}{*}{,70 } \\
\hline & & Erkek & 255 & 37,36 & 7,51 & & \\
\hline & \multirow[b]{2}{*}{ Geçimlilik } & Kadın & 15 & 28,86 & 2,23 & \multirow[b]{2}{*}{1178,50} & \multirow[b]{2}{*}{, $01^{*}$} \\
\hline & & Erkek & 255 & 26,75 & 3,46 & & \\
\hline & \multirow{2}{*}{ Duygusal Denge } & Kadın & 15 & 15,66 & 5,12 & \multirow{2}{*}{1620,50} & \multirow[t]{2}{*}{,32 } \\
\hline & & Erkek & 255 & 14,56 & 5,22 & & \\
\hline
\end{tabular}

Araştırmada, okul yöneticilerinin ertelemecilik davranışlarına, iş yüklerine ve kişilik özelliklerine ilişkin algıları cinsiyet değişkenine göre değerlendirildiğinde; araştırmaya katılan yöneticilerin cinsiyet değişkenine göre ertelemecilik davranışlarına ilişkin algıları arasında istatistiksel olarak anlamlı bir farklıık olduğu görülmektedir $(U=916,50 ; p=.00)$. Katılımcıların 
ertelemecilik ölçeğinden almış oldukları aritmetik ortalamalar incelendiğinde, erkek yöneticilerin ( $\bar{X}=19,97)$, kadın yöneticilere ( $\bar{X}=15,73$ ) oranla daha ertelemeci oldukları görülmektedir.

Türkiye'de genelde yönetici düzeyinde, özelde eğitim yönetiminde kadın sayısının erkeklere oranla oldukça az olduğu bilinen bir gerçektir (Çelikten, 2004a; Dönmez ve Güneş, 2001). Bu araştırma kapsamındaki yöneticiler de cinsiyet açısından incelendiğinde, araştırmaya katılan yöneticilerin yaklaşık \% 95'inin erkek $(n=255), \% 5^{\prime}$ inin ise kadın $(n=15)$ olduğu görülmektedir. Araştırmada bayan müdür sayısının erkek müdür sayısına oranla oldukça az olduğunun belirlenmesi nedeniyle, cinsiyet değişkeni açısından yapılan analizlerde, nonparametrik test yapılması tercih edilmiştir (Hayran ve Özdemir, 1994). Bu nedenle araştırmada cinsiyet değişkeni açısından katıımcıların görüşlerinin farklılaşıp farklılaşmadığını belirlemek için Mann Whitney $U$ testi kullanılmıştır. Yapılan Mann Whitney $U$ testi sonuçları Tablo 2 'de verilmiştir.

Okul müdürlerinin liderlik ve yöneticilik özelliklerini, cinsiyet açısından değerlendirmeyi amaçlayan bazı çalışmalardan (Çelikten ve Yeni, 2004) elde edilen sonuçlar, kadın yöneticilerin okul yönetiminde daha esnek ve demokratik tavırlar gösterebileceklerini ancak işlerinde daha düzenli, titiz, ölçülü ve ciddi olabileceklerini göstermektedir. Benzer biçimde zaman yönetimi ile ilgili bazı araştırma sonuçları, kadın yöneticilerin erkeklere oranla zamanlarını daha iyi yönettiklerini göstermektedir (Erdem, 1997). Bu açıdan bakıldığında, erkek yöneticilerin kadınlara oranla daha ertelemeci olmaları, beklenen bir durum olarak değerlendirilebilir.

Iş yüküne ilişkin bulgular cinsiyet değişkeni açısından incelendiğinde, kadın ve erkek yöneticilerin görüşleri arasında, istatistiksel olarak anlamlı farklılık olduğu görülmektedir $(U=911,50 ; p=.00)$. Her iki grubun iş yükü ölçeğinden almış oldukları aritmetik ortalamalar incelendiğinde, erkek yöneticilerin ölçekte yer alan maddelere "orta düzeyde" katıldıkları ( $\bar{X}$ $=21,72$ ), kadın yöneticilerin ise "kısmen" ( $\bar{X}=16,66)$ katılıkları görülmektedir. Bu bulgu, erkek yöneticilerin kadın yöneticilere oranla iş yüklerini daha fazla algıladıklarını göstermektedir. Araştırmanın bu bulgusu yöneticilerin zaman yönetimi becerileri ile ilişkili olabilir. Yukarıda da belirtildiği gibi, yapılan bazı araştırma sonuçları kadın yöneticilerin zamanlarını daha iyi yönettiklerini göstermektedir (Erdem, 1997). Bu açıdan bakıldığında araştırmanın bu bulgusunun beklentilerle uyumlu olduğu söylenebilir. Bu durumun, yöneticilerin yetki ve sorumluluk devrine ilişkin uygulamaları ile ilişkili olabileceği de söylenebilir. Yapılan bazı araştırmalarda (Özdevecioglu ve ark., 2003), kadın yöneticilerin, erkek yöneticilere oranla daha demokratik oldukları, erkeklerin otoriter tarzlarına göre kadınların insan odaklı ve destekleyici yönetim tarzlarının ön plana çıkardıkları belirtilmiştir. Bu bağlamda kadınların destekleyici ve demokratik yönetim anlayışının bir gereği olarak bazı rol ve yetkilerini paylaşmış olabilecekleri, bu durumunda iş yüklerini az algılamalarına sebep olabileceği düşünülebilir.

Kişilik ölçeğinin sorumluluk alt boyutundan alınan toplam puanlar üzerinden yapılan Mann Whitney $U$ testi sonucunda, cinsiyet açısından yöneticilerin görüşleri arasında anlamlı bir farklııı olmadığı belirlenmiştir $(U=1802,50 ; \quad p=.70)$. Katılımcıların aritmetik ortalamaları incelendiğinde, hem kadın ( $\bar{X}=38,00$ ) hem de erkek yöneticilerin sorumluluk ölçeğinde yer alan ifadelere "çoğunlukla" katıldıkları görülmektedir. Bu bulgu ışığında, her iki gruptaki yöneticiler de kendilerini çoğunlukla sorumlu bireyler olarak algılamaktadırlar. Katılımcıların aritmetik ortalamaları incelendiğinde, kadın yöneticiler $(\bar{X}=38.00)$ erkek yöneticilere oranla $(\bar{X}=37.36)$ kendilerini daha sorumlu olarak algılamaktadırlar. Kadınların geleneksel aile içi rollerinin de gereği olarak erkeklere oranla sorumluluklarının daha fazla olması, kadın yöneticilerin kendilerini daha sorumlu kişilik özelliğine sahip olan bireyler olarak algılamalarına neden olmuş olabilir.

Kişilik ölçeğinin geçimlilik alt boyutu incelendiğinde, katılımcıların algılarının cinsiyet değişkeni açısından anlamlı bir şekilde farklılık gösterdiği $(U=1178,50 ; p=.01)$ görülmektedir. Katılımcıların aritmetik ortalamaları incelendiğinde, kadın yöneticilerin $(\bar{X}=28,86)$ erkek yöneticilere oranla $(\bar{X}=26,75)$ kendilerini daha geçimli olarak algıladıkları söylenebilir. Bu 
durum cinsiyet rolleri ile ilişkili olabilir. Sosyolojik ve kültürel bazı etkenlerden dolayı toplum, kadınlardan nazik ve anlayışlı olmalarını, çevresindeki insanları dikkate almalarını ve içten olmalarını bekler. Erkeklerin ise iddialı ve bağımsız olmaları, başarıyı hedeflemeleri ve girişken olmaları beklenir (Durmuş, 2001; 68). Bu toplumsal beklentiler ve roller zamanla insanların tutum ve davranışlarını etkileyebilmekte, kadınların erkeklere göre daha uyumlu ve geçimli olmalarına neden olabilmektedir. Bazı araştırma bulguları, bu durumu doğrulamaktadır. Örneğin Aykan (2004) tarafından banka çalışanları üzerinde yürütülmüş olan bir çalışmada, kadın yöneticilerin erkeklere göre çalışanlara karşı daha toleranslı ve demokratik oldukları, erkeklerin otoriter tarzlarına karşın, kadınların insan odaklı ve destekleyici yönetim tarzlarını tercih ettikleri belirtilmiş̧ir.

Duygusal denge alt boyutuna ilişkin bulgular cinsiyet değişkeni açısından incelendiğinde, yönetici algıları arasında anlamlı bir farklılık olmadığı görülmektedir $(U=1620,50 ; p=.32)$. Her iki gruptaki yöneticilerin de, ölçekte yer alan ifadelere "kısmen" katıldıkları görülmektedir. Ancak katılımcıların ölçekten aldıkları aritmetik ortalamalar incelendiğinde, istatistiksel olarak anlamlı farklıık olmasa da, erkek yöneticilerin $(\bar{X}=14.56)$ kadın yöneticilere oranla $(\bar{X}=15.66)$ kendilerini duygusal açıdan daha dengeli algıladıkları görülmektedir. Duygusal dengesizlik özelliğinin bir boyutu da endişe ve alınganlığı (Yürür, 2009) ifade etmektedir. Kadınların da erkeklere oranla daha alıngan, endişeli, ayrıntıcı tavırlarının olması, kendilerini duygusal açıdan daha dengesiz algılamalarına neden olmuş olabilir.

\section{Tablo 3:}

Okul Yöneticilerinin Ertelemecilik Davranışları, Iş Yükleri ve Kişilik Özelliklerine ilişkin Algılarının Branş Değişkenine Göre Analiz Sonuçları

\begin{tabular}{|c|c|c|c|c|c|c|c|c|}
\hline \multicolumn{2}{|c|}{ Boyut } & Branş & $\mathbf{N}$ & $\bar{X}$ & $\mathbf{S}$ & Sd & $\mathbf{t}$ & $\mathbf{p}$ \\
\hline \multirow{3}{*}{\multicolumn{2}{|c|}{ Ertelemecilik }} & Sınıf Öğretmeni & 85 & 19.70 & 5.29 & \multirow{3}{*}{268} & \multirow{3}{*}{.066} & \multirow{3}{*}{.09} \\
\hline & & & & & & & & \\
\hline & & Branş Öğretmeni & 185 & 19.75 & 5.19 & & & \\
\hline \multirow{2}{*}{\multicolumn{2}{|c|}{ İş yükü }} & Sınıf Öğretmeni & 85 & 21.28 & 5.40 & \multirow{2}{*}{268} & \multirow{2}{*}{.304} & \multirow{2}{*}{.76} \\
\hline & & Branş Öğretmeni & 185 & 21,51 & 5,98 & & & \\
\hline \multirow{6}{*}{ 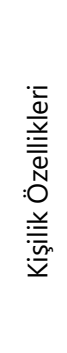 } & \multirow{2}{*}{ Sorumluluk } & Sınıf Öğretmeni & 85 & 37.56 & 8.41 & \multirow{2}{*}{268} & \multirow{2}{*}{.242} & \multirow[b]{2}{*}{.81} \\
\hline & & & 185 & 37.32 & 6.88 & & & \\
\hline & \multirow{2}{*}{ Geçimlilik } & Sınıf Öğretmeni & 85 & 26.48 & 3.13 & \multirow{2}{*}{268} & \multirow{2}{*}{1.270} & \multirow{2}{*}{.20} \\
\hline & & Branş Öğretmeni & 185 & 27.05 & 3.56 & & & \\
\hline & \multirow[b]{2}{*}{ Duygusal Denge } & Sınıf Öğretmeni & 85 & 13.83 & 4.83 & \multirow[b]{2}{*}{268} & \multirow[b]{2}{*}{1.686} & \multirow[b]{2}{*}{.09} \\
\hline & & Branş Öğretmeni & 185 & 14.98 & 5.36 & & & \\
\hline
\end{tabular}

${ }^{*} \mathrm{p}<, 05$

Okul yöneticilerinin ertelemecilik davranışlarına, iş yüklerine ve kişilik özelliklerine ilişkin algıları branş değişkenine göre değerlendirildiğinde; branş $(\bar{X}=19.75)$ ve sınıf öğretmenliğinden $(\bar{X}=19.70)$ gelen yöneticilerin, ertelemeciliğe ilişkin benzer algılara sahip oldukları söylenebilir ( $\mathrm{t}=.066 ; \mathrm{p}=.09$ ). Branş öğretmeni olan yöneticilerde ertelemeciliğin daha fazla olduğu belirlenmiştir. Çocukların geleceklerini biçimlendirmede, sağlıklı bir kişilik kazandırmada büyük rolleri olduğunun bilincinde olan sınıf öğretmenleri işlerini branş öğretmenlerine oranla daha az ertelemeye özen gösteriyor ve öğretmenlik yıllarında işleri ertelememe konusunda gösterdikleri özeni, yöneticilikte de sürdürüyor olabilirler.

İş yüküne ilişkin bulgular incelendiğinde, yöneticilerin görüşleri arasında branş değişkeni açısından, istatistiksel olarak anlamlı farklılık olmadığı görülmektedir $(t=.304 ; p=.76)$. Her iki gruptaki yöneticiler de iş yüklerini "orta düzeyde" algılamaktadırlar. Katılımcıların aritmetik 
ortalamaları incelendiğinde, branş ( $\bar{X}=21.51)$ ve sınıf öğretmenliğinden ( $\bar{X}=21.28)$ gelen yöneticilerin, iş yüklerine ilişkin benzer algılara sahip oldukları ancak branş öğretmenlerinin sınıf öğretmenlerine oranla iş yüklerini daha fazla algıladıkları görülmektedir. Branş öğretmenlerinin sınıf öğretmenlerine oranla farklı alanlarda çalışabilme imkânlarının olması iş yüklerini daha fazla algılamalarına neden olmuş olabilir.

Yöneticilerin kişilik özelliklerinin sorumluluk alt boyutuna ilişkin algılarının, branş değişkeni açısından anlamlı bir şekilde farklılaşmadığı görülmektedir $(\mathrm{t}=.242, \mathrm{p}=.81)$. Her iki gruptaki yöneticiler de kendilerini çoğunlukla sorumlu bireyler olarak algılamaktadırlar. Katılımcıların aritmetik ortalamaları incelendiğinde, sınıf $(\bar{X}=37,56)$ ve branş $(\bar{X}=37,32)$ öğretmenliğinden gelen yöneticilerin, sorumluluk ölçeğinde yer alan ifadelere "çoğunlukla" katıldıkları görülmekte ancak sınıf öğretmeni olan yöneticilerin, branş öğretmeni olan yöneticilere oranla kendilerini daha sorumlu algıladıkları görülmektedir. Bu durum, sınıf öğretmenliğinin öğrencilerin yaşları, yapılan etkinliklerin çeşitliliği ve öğretmenin etki gücü itibariyle daha fazla sorumluluk gerektirmesi ile açılanabilir.

Yöneticilerin, branş değişkeni açısından geçimlilik alt boyutuna ilişkin algı puan ortalamaları arasında anlamlı bir farklılık olmadığı belirlenmiştir $(t=1.270, p=.20)$. Her iki gruptaki yöneticiler de kendilerini "orta düzeyde" geçimli bireyler olarak algılamaktadırlar. Aritmetik ortalamalar incelendiğinde sınıf ( $\bar{X}=26,48$ ) ve branş ( $\bar{X}=27,05)$ öğretmeni olan yöneticilerin, geçimlilik alt boyutunda yer alan ifadelere "orta düzeyde" katılmakta e branş öğretmenlerinin kendilerini daha geçimli olarak algılamaktadırlar. Branş öğretmenlerinin okulda birlikte geçirdikleri zamanın sınıf öğretmenlerine oranla daha az olması, asgari düzeyde iletişim kurdukları için daha az sorun yaşamaları nedeniyle kendilerini sınıf öğretmenlerine oranla daha geçimli olarak algılamış olabilirler.

Tabloda yer alan bulgular, branş değişkenine göre duygusal denge boyutu açısından incelendiğinde, yönetici görüşleri arasında anlamlı bir farklılık olmadığı görülmektedir ( $t=1,686$ $\mathrm{p}=.09)$. Katılımcıların aritmetik ortalamaları incelendiğinde, sınıf $(\bar{X}=13.83)$ ve branş $(\bar{X}$ =14.98) öğretmeni olan yöneticilerin duygusal denge alt boyutunda yer alan ifadelere "kısmen" katıldıkları görülmektedir. Ölçekten alınan düşük puanların duygusal açıdan dengeli bir kişilik özelliğini temsil ettiği düşünüldüğünde, her iki gruptaki yöneticilerin de kendilerini "çoğunlukla" duygusal açıdan dengeli bireyler olarak algıladıkları söylenebilir.

Okul yöneticilerinin ertelemecilik davranışlarına, işyüklerine ve kişilik özelliklerine ilişkin algıları görev türü değişkenine göre incelendiğinde; araştırmaya katılan yöneticilerin ertelemecilik davranışlarına ilişkin algıları arasında anlamlı bir farklılık olmadığı görülmektedir

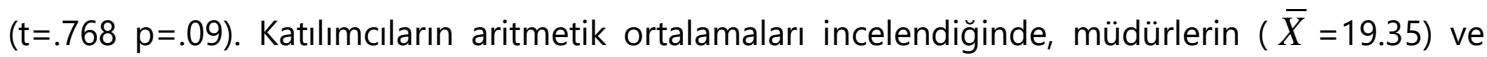
müdür yardımcılarının ( $\bar{X}=19.89$ ) ertelemeciliğe ilişkin benzer algılara sahip oldukları görülmektedir. İstatistiksel olarak anlamlı farklılık gözlenmese de, aritmetik ortalamalar açısından müdür yardımcılarının müdürlere oranla daha ertelemeci oldukları söylenebilir.

Müdürler yönetici olarak okul yönetiminin temel öğesi (Buluç, 2007) ve okulun birinci derecede sorumlu amiri olmalarından ötürü üst makamlardan gelecek her türlü şikâyetle, yaptırımla karşı karşıya kalmaktadırlar. Bu bağlamda müdür yardımcılarına oranla işlerini yaparken geciktirmemeye, zamanında yapmaya daha fazla özen gösteriyor olabilirler. Karakoç (akt: Kaykanacı, 2003) tarafından yapılan bir araştırmada yöneticinin zaman yönetimindeki etkinliği yükseldikçe örgütün etkinliğinin de yükseldiği ortaya konulmuştur. 
Tablo 4:

Okul Yöneticilerinin Ertelemecilik Davranışları, Iş Yükleri ve Kişilik Özelliklerine iliş̧kin Algılarının Görev Türü Değişkenine Göre Analiz Sonuçları

\begin{tabular}{|c|c|c|c|c|c|c|c|c|}
\hline \multicolumn{2}{|c|}{ Boyut } & Görev Türü & $\mathbf{N}$ & $\bar{X}$ & $\mathbf{S}$ & Sd & $\mathbf{t}$ & $\mathbf{p}$ \\
\hline \multirow{2}{*}{\multicolumn{2}{|c|}{ Ertelemecilik }} & Müdür & 77 & 19.35 & 4.63 & \multirow[b]{2}{*}{268} & \multirow[b]{2}{*}{.768} & \multirow[b]{2}{*}{.44} \\
\hline & & Müdür Yardımcısı & 193 & 19.89 & 5.43 & & & \\
\hline \multirow{2}{*}{\multicolumn{2}{|c|}{ İşyükü }} & Müdür & 77 & 22.53 & 4.55 & \multirow[b]{2}{*}{268} & \multirow[b]{2}{*}{1.964} & \multirow[b]{2}{*}{$.05^{*}$} \\
\hline & & Müdür Yardımcısı & 193 & 21.00 & 6.18 & & & \\
\hline \multirow{2}{*}{\multicolumn{2}{|c|}{ Sorumluluk }} & Müdür & 77 & 39.05 & 5.28 & \multirow[b]{2}{*}{268} & \multirow[b]{2}{*}{2.336} & \multirow[b]{2}{*}{$.02 *$} \\
\hline & & Müdür Yardımcısı & 193 & 36.74 & 7.98 & & & \\
\hline \multirow{4}{*}{ 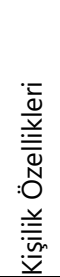 } & \multirow[b]{2}{*}{ Geçimlilik } & Müdür & 77 & 26.40 & 3.69 & \multirow[b]{2}{*}{268} & \multirow[b]{2}{*}{1.425} & \multirow[b]{2}{*}{.15} \\
\hline & & Müdür Yardımcısı & 193 & 27.06 & 3.32 & & & \\
\hline & \multirow[b]{2}{*}{ Duygusal Denge } & Müdür & 77 & 14.02 & 4.93 & \multirow[b]{2}{*}{268} & \multirow[b]{2}{*}{1.187} & \multirow[b]{2}{*}{.23} \\
\hline & & Müdür Yardımcısı & 193 & 14.86 & 5.32 & & & \\
\hline
\end{tabular}

Yöneticilerin iş yüklerine ilişkin algıları görev türü değişkeni açısından incelendiğinde, araştırmaya katılan yöneticilerin görüşleri arasında istatistiksel olarak anlamlı farklılık olduğu görülmektedir ( $\mathrm{t}=1.964 ; \mathrm{p}=.05)$. Katılımcıların aritmetik ortalamaları incelendiğinde, müdürlerin ( $\bar{X}=22.53)$ müdür yardımcılarına oranla $(\bar{X}=21.00)$ iş yüklerini daha fazla algıladıkları görülmektedir. Okul müdürlerinin, öğrenci başarısını yükseltmek, etkili bir öğrenme ortamı oluşturmak, yönetim ekibi ve personel arasında uyum ve işbirliğini sağlamak, örgüt içi ve dışından gelen farklı istekleri karşılamak gibi eğitim-öğretim ve yönetimle ilgili pek çok görevi bulunmaktadır (Çelikten, 2004b; Yavuz, 2006). Bununla birlikte okul müdürü, yasal konumu itibariyle üstlerine karşı okulun işleyişinden birinci derecede sorumludur. Müdürlerin sahip olduğu bu tür sorumlulukların, onların iş yükü algısını etkilemiş olabileceği söylenebilir. Ayrıca okuldaki müdür yardımcısı sayısının artması görev paylaşımını da artıracağından müdür yardımcıları müdürlere oranla iş yüklerini daha az algılamış olabilirler.

Araştırmaya katılan yöneticilerin kişilik özelliklerinin sorumluluk alt boyutuna ilişkin algıları görev türü değişkeni açısından incelendiğinde, katılımcı görüşleri arasında anlamlı bir farklılık olduğu görülmektedir ( $\mathrm{t}=2.336, \mathrm{p}=.02)$. Katılımcıların aritmetik ortalamaları incelendiğinde, müdürlerin ( $\bar{X}=39.05)$ müdür yardımcılarından $(\bar{X}=36.74)$ daha yüksek aritmetik ortalamaya sahip oldukları ve müdürlerin kendilerini daha sorumlu kişilik özelliklerine sahip bireyler olarak algıladıkları belirlenmiştir. Müdürlerin müdür yardımcılarına oranla daha fazla yetkiye ve sorumluluğa sahip olmaları, her hangi bir sorunda birinci derece sorumlu olmaları bu algıya neden olmuş olabilir. Müdür yardımcılarına oranla iş yüklerini daha fazla algılayan müdürlerin kendilerini daha yetkin ve sorumlu hissetmeleri birbirini destekleyen bulgular arasındadır. Baloğlu (2007) tarafından yapılan araştırmada, müdürlerin kendilerini yönetim ile ilgili konularda müdür yardımcılarından daha yeterli algıladıkları sonucu bu bulguyu desteklemektedir.

Yöneticilerin görev türü değişkeni açısından, kişilik ölçeğinin geçimlilik alt boyutuna ilişkin puan ortalamaları arasında anlamlı bir farklılık olmadığı belirlenmiştir $(t=1.425 \mathrm{p}=.15)$. Aritmetik ortalamaları incelendiğinde, müdürlerin $(\bar{X}=26.40)$ ve müdür yardımcılarının, $(\bar{X}=27.06)$ geçimlilik alt boyutunda yer alan ifadelere "orta düzeyde" katıldıkları görülmektedir.

Müdürlerin okulun yasal lideri, okulda otorite ve gücün en önemli simgesi olmaları (Töremen ve Kolay, 2003) ve her türlü yetkiyi kullanma hakkına sahip olmalarından ötürü, 
konumlarını korumanın geçimsiz davranışlarla mümkün olabileceği algısına sahip olmuş olabilirler. Okullarda veliler, öğretmenler ya da öğrenciler yaşadıkları sorunları çözmek ya da bir konuda bilgi almak için çoğunlukla müdür yardımcıları ile muhatap olmaktadırlar. Müdürlere göre daha fazla iletişim içinde olan müdür yardımcılarının iletişim becerileri gelişmiş, bu bağlamda da kendilerini daha geçimli olarak algılamış olabilirler.

Görev türü değişkeni açısından duygusal denge boyutuna ilişkin bulgular incelendiğinde, yöneticilerin görüşleri arasında anlamlı bir farklılık olmadığı görülmektedir ( $\mathrm{t}=1.187, \mathrm{p}=.23$ ). Aritmetik ortalamalar incelendiğinde, müdürler $(\bar{X}=14.02)$ ve müdür yardımcıları $(\bar{X}=14.86)$ kendilerini duygusal açıdan dengeli olarak algılamaktadırlar.

"Okul yöneticilerinin ertelemecilik davranışlarına, iş yüklerine ve kişilik özelliklerine ilişkin algıları okul türü değişkenine göre farklılık göstermekte midir?" sorusuna yanıt bulmak amacı ile veriler $\mathrm{t}$ testi ile değerlendirilmiştir. Bulgular tablo 5 'te sunulmaktadır.

\section{Tablo 5:}

Okul Yöneticilerinin Ertelemecilik Davranışlarına, iş̧ Yüklerine ve Kişilik Özelliklerine ilişkin Algılarının Okul Türü Değişkenine Göre Analiz Sonuçları

\begin{tabular}{|c|c|c|c|c|c|c|c|}
\hline \multicolumn{2}{|l|}{ Boyut } & Okul Türü & $\mathbf{N}$ & $\bar{X}$ & SS & $\mathbf{t}$ & $\mathbf{p}$ \\
\hline \multirow{2}{*}{\multicolumn{2}{|c|}{ Ertelemecilik }} & İlköğretim & 148 & 19.74 & 5.35 & \multirow[b]{2}{*}{.021} & \multirow[b]{2}{*}{.98} \\
\hline & & Ortaöğretim & 122 & 19.72 & 5.07 & & \\
\hline \multirow{2}{*}{ İş yükü } & & İlköğretim & 148 & 21.58 & 5.60 & \multirow{2}{*}{.437} & \multirow{2}{*}{.66} \\
\hline & & Ortaöğretim & 122 & 21.27 & 6.03 & & \\
\hline \multirow{6}{*}{ 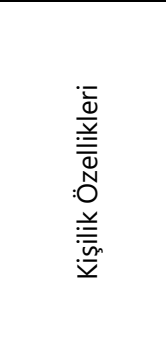 } & \multirow{2}{*}{ Sorumluluk } & İlköğretim & 148 & 37.91 & 7.79 & \multirow{2}{*}{1.264} & \multirow{2}{*}{.20} \\
\hline & & & 122 & 36.77 & 6.83 & & \\
\hline & \multirow{2}{*}{ Geçimlilik } & İlköğretim & 148 & 26.81 & 3.19 & \multirow{2}{*}{.332} & \multirow{2}{*}{.74} \\
\hline & & Ortaöğretim & 122 & 26.95 & 3.73 & & \\
\hline & \multirow[b]{2}{*}{ Duygusal Denge } & İlköğretim & 148 & 14.54 & 5.43 & \multirow[b]{2}{*}{.259} & \multirow[b]{2}{*}{.79} \\
\hline & & Ortaöğretim & 122 & 14.71 & 4.96 & & \\
\hline
\end{tabular}

Illköğretim ve ortaöğretim kurumlarında görev yapan yöneticilerin ertelemecilik davranışlarına ilişkin algıları arasında anlamlı bir farklıık olmadığı görülmektedir ( $t=.021 ; p=.98$ ). Aritmetik ortalamalar incelendiğinde, her iki okul türünde de görev yapan yöneticilerin ertelemeciliğe ilişkin oldukça yakın ortalamalara sahip oldukları görülmektedir. İlköğretim okullarında görev yapan yöneticiler $(\bar{X}=19.74)$, ortaöğretim okullarında görev yapan yöneticilere ( $\bar{X}=19.72$ ) oranla kendilerini daha ertelemeci olarak algılamaktadırlar. Bu algı; ilkokul ve ortaokulların yapılarını ve işleyişlerini etkileyecek özel amaçlarındaki farklııklardan kaynaklanmış olabilir. Kaykanacı (2003) yaptığı araştırmada ilköğretim okulu müdürlerinin tüm yönetim işlerine verdikleri önem kadar zaman harcamadıklarını ifade etmektedir. Aksoy araştırmasında (akt: Kaykanacı, 2003) lise müdürlerinin zamanlarının \%19.3'ünü personel işlerine, \%18'ini eğitim öğretim işlerine harcadıkları sonucuna ulaşmıştır.

Araştırmaya katılan yöneticilerin okul türüne göre iş yükü ölçeğinden aldıkları puanlar incelendiğinde, yöneticilerin ertelemecilik davranışlarına ilişkin algıları arasında anlamlı bir farklıık olmadığı görülmektedir ( $\mathrm{t}=.437 ; \mathrm{p}=.66)$. Illkokulda görev yapan yöneticiler $(\bar{X}=21.58)$, ortaokul okullarında görev yapan yöneticilere $(\bar{X}=21.27)$ oranla iş yüklerini daha fazla algılamaktadırlar.

Bulgular kişilik özelliği açısından okul türü değişkenine göre değerlendirildiğinde, katılımcı görüşleri arasında sorumluluk, geçimlilik ve duygusal denge alt boyutları açısından anlamlı bir 
farklıık olmadığı görülmektedir. Aritmetik ortalamalar açısından değerlendirdiğimizde; ilkokullarda görev yapan yöneticiler ( $\bar{X}=37.91)$, ortaokullarda görev yapan yöneticilere ( $\bar{X}$ $=36.77$ ) oranla kendilerini daha sorumlu kişilik özelliğine sahip bireyler olarak algılamaktadırlar. Ortaokullarda görev yapan yöneticiler $(\bar{X}=26.95)$, ilkokullarda görev yapan yöneticilere ( $\bar{X}$ $=26.81$ ) oranla kendilerini daha geçimli kişilik özelliğine sahip bireyler olarak algılamaktadırlar. Illkokullarda görev yapan yöneticiler $(\bar{X}=14.54)$, ortaokullarda görev yapan yöneticilere ( $\bar{X}$ $=14.71$ ) oranla kendilerini daha dengeli kişilik özelliğine sahip bireyler olarak algılamaktadırlar.

Okul yöneticilerinin ertelemecilik davranışlarına, iş yüklerine ve kişilik özelliklerine ilişkin algıları arasındaki ilişkiye dair veriler üzerinde Pearson Korelasyon Analizi yapılmıştır. Analiz sonuçları Tablo 6' da verilmiştir.

Tablo 6:

Okul Yöneticilerinin Ertelemecilik Davranışlarına, İş Yüklerine ve Kişilik Özelliklerine Iliş̧kin Algıları Arasındaki Iliş̧ki

\begin{tabular}{lllll}
\hline Boyut & $\mathbf{2}$ & $\mathbf{3}$ & $\mathbf{4}$ & $\mathbf{5}$ \\
\hline Ertelemecilik &, $602^{* *}$ &,$- 496^{* *}$ &,- 115 &, $194^{* *}$ \\
İşyükü & 1 &,$- 321^{* *}$ &,- 003 &, $399^{* *}$ \\
Sorumluluk & & 1 &, 076 &,$- 195^{* *}$ \\
Geçimlilik & & 1 &, $157^{* *}$ \\
Duygusal Denge & & & & 1 \\
\hline
\end{tabular}

Büyüköztürk'e (2002:32) göre; korelasyon katsayısının, mutlak değer olarak 0.70-1.00 arasında olması, yüksek; 0.70-0.30 arasında olması, orta; 0.30-0.00 arasında olması ise, düşük düzeyde bir ilişki olarak tanımlanmaktadır. Bu ölçütlere göre tablodaki bulgular incelendiğinde, ertelemecilik ile iş yükü arasında orta düzeyde pozitif yönde $(r=.602, p=.01)$ bir ilişki olduğu görülmektedir. Yöneticilerin ertelemecilik ölçeğinden aldıkları puanlar ile iş yükü ölçeğinden aldıkları puanlar paralel olarak artmakta ya da azalmaktadır. Bu bulgu, yöneticilerin iş yüklerini fazla algıladıkça, erteleme eğilimlerinin de artacağını göstermektedir. Ertelemecilik bireyin kişilik özellikleri, birey-iş uyumu, yönetici-çalışan arasındaki iletişim vb. gibi pek çok değişkenle ilgili bir olgu olarak nitelendirilmektedir. Ancak görev, yetki ve sorumluluklar arasında bir denge kurulamaması durumunda, yöneticilerin iş yükü ve zaman yönetimi açısından sorun yaşamaları muhtemeldir. Müdürün üstesinden gelinemeyecek kadar iş yükünün olması, onun erteleme eğilimlerini etkileyebileceği düşünülebilir ve bu durum müdürlerde stres ve tükenmişlik de yaratabilir. Örneğin okul müdürlerinin işten ayrılma nedenlerini belirlemeyi amaçlayan bir çalışmaya katılan yöneticiler, örgütteki kişisel ilişsilerin sağlıksızlığını, iş yükünün fazla olmasını ve yeterli zamanlarının olmamasını en önemli nedenler olarak belirtmişlerdir (Çelikten, 2004b). Benzer biçimde Ekinci ve Ekici (2003) tarafından yapılan ve yöneticilerin işleriyle ilgili örgütsel stres kaynaklarını belirlemeyi amaçlayan bir diğer araştırmada, bürokratik ve yasal işlemlerin fazla olması, aşırı iş yükü, meslekte ilerleme ve kendini geliştirme fırsatının verilmemesi stres kaynakları olarak belirtilmiştir.

Bulgular kişilik özelliği açısından incelendiğinde, ertelemecilik ile sorumluluk kişilik özelliği arasında orta düzeyde negatif yönde $(r=-.496, p=.01)$, ertelemecilik ile geçimli kişilik özelliği arasında düşük düzeyde negatif yönde $(r=-.115, p=.01)$, ertelemecilik ile duygusal denge arasında düşük düzeyde pozitif yönde $(r=.194, p=.01)$ bir ilişki olduğu görülmektedir. Bu bulgu, yöneticilerin sorumlu, geçimli kişilik özelliklerine sahip olma düzeyleri arttıkça, erteleme eğilimlerinin azalacağını göstermektedir. Ayrıca, yöneticilerin duygusal denge ölçeğinden aldıkları puanlar arttıkça, erteleme eğilimlerinin de artacağı görülmektedir. Duygusal denge ölçeğinden alınan düşük puanlar, duygusal açıdan daha dengeli bir kişilik özelliğini ifade etmektedir. Bu açıdan bakıldığında yöneticilerin duygusal anlamda dengeli olma düzeyleri arttıkça, erteleme eğilimlerinin azaldığı söylenebilir. 
İş yükü ile kişilik özelliklerinden sorumluluk $(r=-.321, p=.01)$ arasında düşük düzeyde negatif yönde bir ilişki, duygusal denge $(r=.399, p=.01)$ arasında ise düşük düzeyde pozitif bir ilişki olduğu görülmektedir. Bir diğer ifade ile yöneticilerin iş yükü ölçeğinden aldıkları puanlar ile kişilik özelliklerinin sorumluluk boyutlarından aldıkları puanlar paralel olarak artmakta ya da azalmaktadır. Bu bulgu, sorumlu kişilik özelliklerine sahip yöneticilerin iş yüklerini daha az algıladıklarını göstermektedir. Duygusal denge kişilik özelliği açısından bakıldığında ise, yöneticilerin duygusal dengeli olma düzeyleri arttıkça, iş yüklerini daha az algıladıkları söylenebilir.

\section{SONUÇ TARTIŞMA VE ÖNERILER}

Araştırmadan elde edilen bulgular ışığında uygulayıcılar ve araştırmacılar için aşağıdaki öneriler geliştirilmiştir. Araştırmaya katılan yöneticilerin kendilerini "orta düzeyde" geçimli olarak algıladıkları bulgusundan hareketle; yöneticilerin birbirleri ile ve öğretmenlerle olan ilişkilerini, iletişimlerini güçlendirmeyi hedefleyen, empati kurmalarını sağlayan bir yönetim anlayışı geliştirmeleri sağlanmalıdır. Bu amaçla yönetim ekibi ve öğretmenler arasında, okul içi iletişim ve etkileşimin artııılmasını sağlayacak etkinlikler düzenlenebilir. Bu anlamda okulda takım çalışmaları özendirilebilir, yöneticiler ve öğretmenler arasında iletişimi arttıracak sosyal faaliyetler düzenlenebilir.

Bulgulara göre; yöneticiler kısmen ertelemecilik davranışları gösterdiklerini belirtirken, öğretmenler yöneticilerinin çoğunlukla ertelemeci davrandıklarını ifade etmektedirler. Bu bulgudan hareketle; bireyin kendisini daha olumlu algılama eğiliminde olduğu göz önünde bulundurulursa, yöneticilerin kendilerini daha gerçekçi olarak algılayabilmeleri, algılarını daha gerçekçi temellere dayandırabilmelerine bağlıdır. Bu nedenle okul yöneticilerine yönelik algı ve iletişim konularında eğitimlere ağırlık verilmelidir.

Araştırmada erkek yöneticilerin kadın yöneticilere oranla daha fazla ertelemecilik davranışları sergiledikleri ve iş yüklerini daha fazla algıladıklarına ilişkin bulgulardan hareketle erkek yöneticilerin örgütsel amaçları doğrudan etkileyecek olan erteleme davranışlarını azaltacak, zaman yönetimi becerilerini artıracak etkinlikler düzenlenebilir.

Araştırmada okul yöneticilerinin ertelemecilik davranışlarına ilişkin algılarını belirlemek amacıyla "okul yöneticileri ertelemecilik davranışları ölçeği" geliştirilmiştir. Geliştirilecek farkı ölçeklerle, okul yöneticileri üzerinde yapılacak araştırmalar sonuçları zenginleştirecektir.

\section{KAYNAKLAR}

Aykan, E.(2004). Kayseri'de faaliyet gösteren girişimcilerin liderlik özellikleri. Sosyal Bilimler Enstitüsü Dergisi, 17(2), 213-224.

Atkinson, R. L., Atkinson, R. C., Smith, E. E., Bem Daryl, J., Nolen-Hoeksema, S. (1999). Psikolojiye giriş, Y. Alagon (Çev.). İstanbul: Arkadaş Yayınevi.

Baloğlu, N.(2007). İlk ve orta öğretim okulu yönetici yardımcılarının alması gereken hizmet içi eğitim konuları hakkında okul yöneticilerinin görüşleri. Ahi Evran Üniversitesi Kırşehir Eğitim Fakültesi Dergisi (KEFAD), 8(1), 167-178.

Baltacı, A. (2017). Erteleme davranışı eğilimi ve beş faktörlü kişilik özellikleri arasındaki ilişkiler: okul yöneticileri üzerine bir araştırma. International Journal of Contemporary Educational Studies (IntJCES) 3 (1) .

Buluç, B. (2007). İlk ve orta öğretim kurumlarında okul yöneticilerinin bilgilendirme işlevini gerçekleştirme düzeyleri. Türk Eğitim Bilimleri Dergisi. 5(1), 1-23.

Büyüköztürk, Ş. (2002). Sosyal bilimler için veri analizi el kitabı. Ankara: Pegem A Yayıncılık.

Cohen, L., Manion, L. ve Morrison, K. (2005). Research methods in education (5thed.). London, New York: Routledge Falmer.

Cüceloğlu, D. (2002) Insan ve davranışı (11. Basım). İstanbul: Remzi Kitabevi. 
Çakıcı, D.Ç. (2003). Lise ve üniversite öğrencilerinde genel erteleme ve akademik erteleme davranışının incelenmesi. (Yayımlanmamış Yüksek Lisans Tezi). Ankara Üniversitesi, Ankara.

Çelikten, M. (2004a). Okul müdürü koltuğundaki kadınlar: Kayseri ili örneği, Erciyes Üniversitesi Sosyal Bilimler Enstitüsü Dergisi, 17(2), 91-118.

Çelikten, M. (2004b). Bir okul müdürünün günlüğü. Fırat Üniversitesi Sosyal Bilimler Dergisi, 14(1), 123-137.

Çelikten, M. ve Yeni, Y. (2004). Okul müdürlerinin liderlik ve yöneticilik özelliklerinin cinsiyet açısından değerlendirilmesi. Gazi Üniversitesi Kastamonu Eğitim Fakültesi Dergisi, 12(2), 305-314.

Chu, A. H. C., ve Choi, J. N. (2005). Rethinking procrastination: Positive effects of "active" procrastination behavior on attitudes and performance. Journal of Social Psychology, 14, 245-264.

Dönmez, B. ve Güneş, H. (2001). İlköğretim okulu yöneticilerinde tükenmişlik, Eğitim Araştırmaları Dergisi, 1(5), 71-78.

Durmuş, E. A. (2001). Kadın ve erkek yöneticilerin liderlik davranışları arasındaki farklılıklar: Türkiye`de seçilmiş bir grup yönetici üzerine bir araştırma. Akdeniz Üniversitesi,Sosyal Bilimler Enstitüsü-İşletme Anabilim Dalı, Antalya.

Ekinci, H. ve Ekici, S. (2003). Yöneticiler üzerindeki etkileri açısından stres kaynakları ve bir uygulama. Uludağ Üniversitesi iktisadi ve Idari Bilimler Fakültesi Dergisi, 22(2), 93-111.

Erdem, R. (1997). Zaman yönetimi ve hastane üst düzey yöneticileri açısından bir uygulama. Hacettepe Üniversitesi Sağlık Bilimleri Enstitüsü Yüksek Lisans Tezi, Ankara.

Ferrari, J. R.; Díaz-Morales, J. F.; O'Callaghan, J.; Díaz, K.; ve Argumedo, D. (2007). Frequent behavioral delay tendencies by adults: International prevalence rates of chronic procrastination, Journal of CrossCultural Psychology, 38(4), 458-464.

Ferrari, J. R., Johnson, J. L., ve McCown, W. G. (1995). Procrastination and task avoidance: Theory, research, and treatment. New York, NY, USA: Plenum Press.

Hayran, M.ve Özdemir, M. (1994). Bilgisayar, istatistik ve tıp. Ankara: Medikomat Basın Yayım.

Johnson, J.L. ve Bloom, M., (1995). An analysis of the contribution of the five factors of personality to variance in academic procrastination. Personality and Individual Differences, 18, 127-133.

Kandemir, M. ; Palancı, M. ; İlhan, T. , Avcı, M.(2017). Sınıf tekrarı yapan öğrencilerin akademik erteleme nedenleri. Erzincan Üniversitesi Eğitim Fakültesi Dergisi, 19 (2), 285-302.

Kaptan, S. (1993). Bilimsel araştırma ve istatistik teknikleri. Ankara: Tekışık Web Ofset Baskı.

Kaykanacı, M. (2003). Illköğretim okulu müdürlerinin yönetim işlerine verdikleri önem ve harcadıkları zaman. Kastamonu Eğitim Dergisi, 11(1), 137-158.

Lay, C. H., ve Brokenshire, R. (1997). Conscientiousness, procrastination, and person-task characteristics in job searching by unemployed adults. Current Psychology, 16, 83-96.

Milgram, N. N., ve Tenne, R. (2000). Personality correlates of decisional and task avoidant procrastination. European Journal of Personality, 14, 141-156.

Özdevecioğlu, M., Bulut E.A., Tekçe E.A., Çirli, Y., Gemici, T., Tozal M. ve diğ. (2003), Kadın ve Erkek Yöneticilerin Yönetimi Altındaki Personelin Motivasyon, Stres ve Tatmini Farklılıklarını Belirlemeye Yönelik Bir Arastırma, Yönetim ve Ekonomi Dergisi, 10(2). 125-138.

Reilly, M. D. (1982).Working wives and convenience consumption. Journal of Consumer Research, 8, 407418.

Sarıkaya Aydın, K.; Koçak, S. (2016). Üniversite öğrencilerinin zaman yönetimi becerileri ile akademik erteleme düzeylerinin incelenmesi. Uşak Üniversitesi Eğitim Araştırmaları Dergisi, 2(3), 654-420.

Şişman, M., ve Turan, S. (2004). Dünyada eğitim yöneticilerinin yetiştirilmesine ilişkin başlıca yönelimler ve Türkiye için çıkarılabilecek bazı sonuçlar. Türk Eğitim Bilimleri, 2(1), 13- 25.

Tomrukçu, B. (2008). Beş faktör kişilik özellikleri ile iş değerleri arasındaki ilişki üzerine bir inceleme. Yayımlanmamış Yüksek Lisans Tezi. Osmangazi Üniversitesi-Eskişehir.

Töremen, F. ve Kolay, Y. (2003). İlköğretim okulu yöneticilerinin sahip olması gereken yeterlikler. Milli Eğitim Dergisi. Sayı: 160.

Watson, D. C. (2001). Procrastination and the five-factor model: A facet level analysis. Personality and Individual Differences, 30, 149-158.

Yavuz, M. (2006). ilköğretim okul müdürlerinden beklenen roller ve karşılanma düzeyleri.Yayımlanmamış Doktora Tezi, Selçuk Üniversitesi Sosyal Bilimler Enstitüsü,Konya.

Yürür, S. (2009). Yöneticilerin çatışma yönetim tarzları ve kişilik özellikleri arasındaki ilişkinin analizine yönelik bir araştırma. C. Ü. Iktisadi ve Idari Bilimler Dergisi, 10 (1). 


\section{The Perceptions of the School Administrators about Procrastination, Personality Traits and Workloads}

\author{
Dr. Melike CÖMERT (Academician) \\ Inönü University-Turkey \\ melike.comert@inonu.edu.tr
}

\author{
Prof.Dr. Burhanettin DÖNMEZ \\ Inönü University-Turkey \\ burhanettin.donmez@inonu.edu.tr
}

\begin{abstract}
This research is purposed to determine the school administrators perceptions about their procrastination behavior, workload, and personality traits by quantitative research techniques in the sample of 270 school administrators (77 principals and 193 vice-principals) working in the primary and high schools located in central district of Malatya province. For the quantitative research, 'survey model' was used. The data of the research were collected with 'Procrastination Scale for School Administrators', developed by the researcher, 'Role-Oriented Workload Scale' and 'Big Five Factor Personality Scale' scales. The variables of gender, subject, duty, school type, were also examined in the relation between procrastination behavior, workload, and personality traits. Based on the findings of the research, it was concluded that administrators display procrastination behaviors partially, they perceive their workload at moderate level, they 'generally' agree with the conscientiousness subscale of the personality scale, moderately agree with the 'agreeableness' subscale, and 'generally' agree with the neuroticism subscale. A moderate positive correlation was found between procrastination and workload $(r=.602, p=.01)$, a moderate negative correlation was found between procrastination and conscientiousness personality trait $(r=-.496, p=.01)$, and a slight negative correlation was found between workload and conscientiousness subscale $(r=-.321, p=.01)$. It is expected that school administrators should be internally supervised in order to avoid postponement of their duties from the findings of their work, and have a high level of work satisfaction and organizational commitment for task internalizations. Effective time management and internal audit skills of administrators should be developed.
\end{abstract}

Keywords: School administrators, procrastination behavior, workload, personality traits

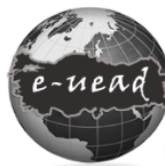

E-International Journal of Educational Research, Vol: 9, No:2x, 2018, pp. 1-18

DOI: 10.19160/ijer.409300

Received: 24.03 .2018 Accepted: 24.05.2018

\section{Suggested Citation:}

Cömert, M. \&. Dönmez, B. (2018). The perceptions of the school administrators about procrastination, personality traits and workloads, E-International Journal of Educational Research, Vol: 9, No: 2, 2018, pp. 1-18, DOI: 10.19160/ijer.409300 


\section{EXTENDED ABSTRACT}

\section{Introduction}

Researchs were indicated that the procrastination behavior or procrastination tendency is a common problem among individuals from all walks of life. (Çakıcı, 2003; Kandemir, 2017). Milgram and Tenne (2000) describe procrastination as a personality trait, or behavioral predisposition to delay work, duty, or to avoid decision making. Procrastination can be defined as consciously initiating, maintaining, and completing a duty as superfluous or unintentional, and making it a habit, despite having the resources, authority and ability to carry out a task. The aim of this research is to determine the school administrators perceptions about their procrastination behavior, workload, and personality traits.

\section{Method}

The data for this research were collected using quantitative research techniques like survey model. In order to ensure that the instruments of the research are responded accurately, thus increasing the reliability and validity of the research, pilot and actual studies were conducted on two distinct principal populations. The population of the pilot study comprised a total of 127 school administrators (34 principals and 93 vice principals) working in the primary and high schools located in the central district of Bingöl province. Given that whole population was accessible, all of the school administrators were covered without selecting sample out of it. The second population, which is the actual subject group of research, was consist of 368 school administrators (110 principals and 258 vice principals) working in the primary and high schools located in central district of Malatya province. The sample of the research consisted 270 school administrators (77 principals and193 vice-principals) who volunteered to participate into the study. The quantitative data of the research were collected through three different scales. 'Procrastination Scale for School Administrators', developed by the researcher, was used in order to determine the procrastination behavior of the administrators. 'Role-Oriented Workload Scale', which was originally developed by Reilly (1982) and Turkish validity and reliability studies of which were done by the researcher was used to measure the administrators perceptions of workload. Moreover, 'Big Five Factor Personality Scale', validity and reliability studies of which were done by Tomrukçu (2008), was used to determine the personality traits of the school administrators. Prior to the analysis of the quantitative data, Levene's test for homogeneity of variances was used to test the homogeneity of the variances. Where variances were homogeneous, t-test was used to test the differences between participants perceptions in terms of gender, subject, and duty variables, whereas One-way Anova test was used for comparisons between groups in terms of school type. In order to determine the association between administrators procrastination behaviors and their workload and personality traits, Pearson Correlation analysis was used. Where variances were not homogeneous, t-test was replaced by Mann Whithney-U, and One-way Anova test was replaced by Kruskall Wallis-H Test. SPSS 14.0 (Statistical Package for The Social Sciences) software was used in statistical analyses of the data obtained through research instruments.

\section{Findings}

Based on the findings of the research, it was concluded that administrators display procrastination behaviors partially, they perceive their workload at moderate level, they 'generally' agree with the conscientiousness subscale of the personality scale, moderately agree with the 'agreeableness' subscale, and generally agree with the neuroticism subscale. The gender related findings of the research revealed that male administrators procrastinate more than female administrators, and they perceive their workload heavier than their female colleagues. No significant difference was observed between female and male administrators views about conscientiousness and neuroticism subscales of the personality scale. In terms of agreeableness subscale, it was found that female administrators perceive themselves as more 
agreeable than female administrators. In terms of duty variable, no significant difference was found between administrators perceptions about procrastination behaviors and agreeableness and neuroticism subscales of personality traits scale. Statistically significant differences were found between administrators perceptions about their workload and conscientiousness subscale of personality traits scale, according to duty variable. Accordingly, principals perceive themselves as having more workloads and responsible personality trait than vice-principals. Finally, a moderate positive correlation was found between procrastination and workload $(r=.602, p=.01)$, a moderate negative correlation was found between procrastination and conscientiousness personality trait $(r=-.496, p=.01)$, and a slight negative correlation was found between workload and conscientiousness subscale $(r=-.321, p=.01)$.

\section{Conclusion}

It is expected that school administrators should be internally supervised in order to avoid procrastinate of their duties from the findings of their work, and have a high level of work satisfaction and organizational commitment for task internalizations. Effective time management and internal audit skills of administrators should be developed. 
Ek 1. Okul Yöneticilerinin Ertelemecilik Davranışları Ölçeğine İlişkin Açıklayıcı Faktör Analizi Sonuçları

\begin{tabular}{|c|c|c|}
\hline Madde & Faktör Yükü & $\begin{array}{l}\text { Madde-Toplam } \\
\text { Korelâsyonu }\end{array}$ \\
\hline $\begin{array}{l}\text { 1. Personele yönelik seminerler ve hizmet içi eğitimler } \\
\text { geciktirilmeden duyurulur. }\end{array}$ & .763 & $.745^{\star *}$ \\
\hline $\begin{array}{l}\text { 2. Personelin özlük, maaş ve ders ücretleri ile ilgili işleri } \\
\text { zamanında yapılır. }\end{array}$ & .703 & $.677^{* *}$ \\
\hline $\begin{array}{l}\text { 3. Öğrenci kayıt, devam-takip ve not işleri zamanında } \\
\text { yapılır. }\end{array}$ & .690 & $.682^{* *}$ \\
\hline $\begin{array}{l}\text { 4. Öğretmen nöbet çizelgelerinin hazırlanmasında } \\
\text { gecikmeler olur. }\end{array}$ & .670 & $.624^{* *}$ \\
\hline $\begin{array}{l}\text { 5. Okulda düzenlenecek etkinliklerle (örn. spor, kültür, } \\
\text { sanat vb.) ilgili görevlendirmeler geciktirilmeden yapılır. }\end{array}$ & .670 & $.644^{* *}$ \\
\hline $\begin{array}{l}\text { 6. Öğretmenler alınan kararlar konusunda zamanında } \\
\text { bilgilendirilir. }\end{array}$ & .642 & $.658^{* *}$ \\
\hline $\begin{array}{l}\text { 7. Resim, şiir, kompozisyon vb. yarışmalar öğretmenlere } \\
\text { zamanında duyurulur. }\end{array}$ & .640 & $.607^{* *}$ \\
\hline $\begin{array}{l}\text { 8. Ders dağılımları ve haftalık ders çizelgeleri eğitim- } \\
\text { öğretim yılı başında tamamlanmış olur. }\end{array}$ & .634 & $.637^{* *}$ \\
\hline $\begin{array}{l}\text { 9. Karar alma süreci o kadar uzun sürer ki, çözüme } \\
\text { ulaşmak için iş işten geçmiş olur. }\end{array}$ & .589 & $.586^{* *}$ \\
\hline Öğretmen ve veli toplantıları zamanında yapılır. & .572 & $.602^{* *}$ \\
\hline $\begin{array}{l}\text { 11. Teknolojik donanımların (fotokopi makineleri, } \\
\text { bilgisayarlar vb.) bakımı, onarımı gecikmeden yapılır. }\end{array}$ & .551 & $.581^{\star \star}$ \\
\hline Süreli evraklara zamanında yanıt verilir. & .539 & $.550 * *$ \\
\hline Resmi yaptırımı olmayan yazışmalar son ana bırakılır. & .516 & $.522 * *$ \\
\hline $\begin{array}{l}\text { 14. Okul binasının donanımı (boya, temizlik malzemesi } \\
\text { vb.) ile ilgili malzemelerin alımında gecikmeler olur. }\end{array}$ & .464 & $.524^{* *}$ \\
\hline
\end{tabular}

Özdeğer (Eigenvalue) $\quad 5.425$

Açıklanan Kümülâtif Varyans \% 38.750

İç Tutarlılık Katsayısı (Cronbach Alpha) $\quad .868$ 
Ek 2. Rol Kaynaklı İş yükü Ölçeğine Illişkin Açıklayıcı Faktör Analizi Sonuçları

\begin{tabular}{|c|c|c|}
\hline Madde & Faktör Yükü & $\begin{array}{c}\text { Madde-Toplam } \\
\text { Korelâsyonu }\end{array}$ \\
\hline $\begin{array}{l}\text { 1. Yapmak zorunda olduğum işlere ne zamanım ne } \\
\text { de enerjim yetiyor. }\end{array}$ & .637 & $.629^{* *}$ \\
\hline $\begin{array}{l}\text { 2. Benden beklenen işler o kadar çok ki zamanım } \\
\text { yetmiyor. }\end{array}$ & .760 & $.754^{\star *}$ \\
\hline $\begin{array}{l}\text { 3. Yapmam gereken işleri yetiştirmek için gün içinde } \\
\text { daha fazla zamana ihtiyacım var. }\end{array}$ & .694 & $.698^{\star \star}$ \\
\hline 4. Hiçbir işi yetiştiremiyorum. & .688 & $.667^{\star \star}$ \\
\hline 5. Kendime hiç vakit ayıramıyorum. & .683 & $.687^{\star *}$ \\
\hline $\begin{array}{l}\text { 6. Zaman zaman insanların beklentilerini } \\
\text { karşılayamadığım oluyor. }\end{array}$ & .699 & $.679 * \star$ \\
\hline $\begin{array}{l}\text { 7. Çoğu zaman yapmam gereken işleri ertelemek } \\
\text { zorunda kalıyorum. }\end{array}$ & .674 & $.653^{* *}$ \\
\hline $\begin{array}{l}\text { 8. Tanıdığım diğer yöneticilere göre çok daha fazla } \\
\text { iş yüküm var. }\end{array}$ & .547 & $.588^{\star *}$ \\
\hline $\begin{array}{l}\text { 9. O kadar çok işim var ki tüm işlerimi unutmadan } \\
\text { yetiştirmek için bir öncelik listesi hazırlamam } \\
\text { gerekiyor. }\end{array}$ & .598 & $.623^{\star *}$ \\
\hline Özdeğer (Eigenvalue) & 4.007 & \\
\hline Açıklanan Kümülâtif Varyans & $\% 44.517$ & \\
\hline İç Tutarlılık Katsayısı (Cronbach Alpha) & 837 & \\
\hline
\end{tabular}

